\title{
Hegemoni Kekuasaan dan Ideologi dalam Novel Pulang Karya Tere Liye (Sebuah Kajian Sosiologi Sastra)
}

\author{
Kuswatun Khasanah \\ Universitas Indraprasta PGRI \\ Jalan Nangka No. 58 C/TB. Simatupang, Tanjung Barat, Jakarta Selatan 12530 \\ Anna_Kendra@yahoo.co.id
}

\begin{abstract}
The research aims to find out how the connection between the hegemony of power and ideology, and its presentation in the novel Pulang karya Tere Liye. The research was conducted with qualitative research methods, analyzing, and describing the hegemony of power and ideology found in the novel with Gramsci's theory of hegemony approach, Sociology Literature study. The technique used is content analysis based on the sequence of problems that have been formulated, descriptively qualitatively, namely by collecting, processing, analyzing and presenting data objectively. The results of the discussion obtained the following conclusions: 1) The occurrence of power hegemony from the ruling class is closely related to the ideology adopted by figures as representatives of certain social groups; the ruling ideology that places power above all else, justifies any means, power can be sought with money, and power and glory are built with cooperation, resulting in him doing hegemony to a low social class whose ideology is loyal and obedient to the authorities. 2) The ruling class's hegemony to other social classes occurs both voluntarily and forcibly, which is depicted in characterization, space and time, and in each storyline, both in storytelling and backlighting, in the story of Bujang's journey in supporting the Tong family in the practice. 3) The ideology of the ruling class and the class that is controlled, clearly illustrated in every event that is intertwined in a unity of challenging paths, integrity and unity of content and meaning woven together coherently, resulting in power hegemony can occur, so the author is able to express his social criticism clearly and straightforward.
\end{abstract}

Keywords: power hegemony, ideology, novels

\begin{abstract}
Abstrak
Penelitian bertujuan untuk mengetahui bagaimana kaitan antara hegemoni kekuasaan dengan ideologi, serta penyajiannya dalam novel Pulang karya Tere Liye. Penelitian dilakukan dengan metode penelitian kualitatif, menganalisis, dan mendeskripsikan hegemoni kekuasaan dan ideologi yang terdapat pada novel dengan pendekatan teori hegemoni Gramsci, kajian Sosiologi Sastra. Teknik yang digunakan adalah analisis isi berdasarkan urutan masalah yang telah dirumuskan, secara deskriptif kualitatif, yaitu dengan mengumpulkan, mengolah, menganalisis dan menyajikan data secara objektif. Hasil pembahasan diperoleh kesimpulan sebagai berikut: 1) Terjadinya hegemoni kekuasaan dari kelas penguasa berkaitan erat dengan ideologi yang dianut tokoh sebagai wakil dari kelompok sosial tertentu; ideologi penguasa yang menempatkan kekuasaan di atas segalanya, menghalalkan segala cara, kekuasaan dapat diupayakan dengan uang, serta kekuasaan dan kejayaan dibangun dengan kerja sama, mengakibatkannya melakukan hegemoni kepada kelas sosial rendah yang berideologi setia dan patuh kepada penguasa. 2) Hegemoni kelas berkuasa kepada kelas sosial llain terjadi baik secara sukarela maupun terpaksa, yang digambarkan pada penokohan, latar ruang dan waktu, serta dalam setiap alur cerita, baik dalam penceritaan maupun sorot balik, pada kisah perjalanan Bujang dalam mendukung keluarga Tong dalam praktik tersebut. 3) Ideologi kelas berkuasa maupun kelas yang dikuasai, tergambar secara jelas pada setiap peristiwa yang terjalin dalam kesatuan alur yang menantang, keutuhan serta kesatuan isi dan makna yang dijalin
\end{abstract}

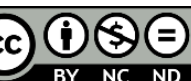

Creative Commons Attribution-NonCommercial-NoDerivatives 4.0 International License 
secara runtut, yang mengakibatkan hegemoni kekuasaan dapat terjadi, sehingga pengarang mampu menyampaikan kritik sosialnya secara jelas dan lugas.

Kata Kunci: hegemoni kekuasaan, ideologi, novel

\section{PENDAHULUAN}

Novel sebagai salah satu genre sastra, menjadi cerminan masyarakat, yang menampilkan dan merefleksikan kondisi sosial serta keadaan yang terjadi di suatu masyarakat pada masa tertentu. Dalam ilmu sastra, novel tersebut dikategorikan sebagai sosial-historis. Novel terlahir di tengah masyarakat dan menggambarkan situasi, kondisi, serta gejala-gejala ataupun realitas sosial yang terjadi di sekitarnya. Selain itu, juga menjadi sarana untuk mencatat kejadian-kejadian dalam fakta kultural. Adanya realitas sosial dan lingkungan yang berada di sekitar pengarang menjadi bahan dalam menciptakan karya sehingga memiliki hubungan erat dengan kehidupan baik berkaitan dengan kejadian sosial, moralitas, keagamaan, maupun kondisi-kondisi produktif masyarakat sekitarnya (Watt dalam Rokhmansyah, 2010).

Menurut H.B Jassin, novel adalah cerita mengenai suatu episode dalam kehidupan manusia, suatu kejadian yang luar biasa dalam kehidupan itu, sebuah krisis yang memungkinkan perubahan nasib pada manusia (Purba, 2010). Menurut Reeve dalam Wellek \& Warren (2000), novel adalah gambaran dari kehidupan dan perilaku yang nyata, dari zaman pada saat novel itu ditulis. Berdasarkan pengertian tersebut, dapat disintesis bahwa novel merupakan prosa rekaan yang panjang, yang menceritakan kehidupan manusia dan tersusun dari unsur-unsur pembangun dan pembentuknya, yaitu peristiwa-peristiwa, penokohan, pengaluran, dan latar yang menggambarkan realitas sosial yang terjadi pada suatu masa novel tersebut ditulis.

Karya sastra khususnya novel memiliki pengaruh yang besar terhadap perubahan sosial bangsa Indonesia terutama dalam hal pola pikir. Contohnya pada Novel Siti Nurbaya karya Marah Rusli yang mampu membuka pola pikir masyarakat sejak zaman dahulu mengenal budaya kawin paksa. Novel tersebut memberikan kesan pada pembaca bahwa kawin paksa merupakan suatu hal yang negatif. Dengan adanya novel tersebut pola pikir masyarakat lambat laun berubah terutama sudut pandangnya dalam menyikapi budaya itu.

Kekuasaan adalah kewenangan yang didapatkan oleh seseorang atau kelompok guna menjalankan kewenangan tersebut, wewenang tidak boleh dijalankan melebihi kewenangan yang diperoleh atau kemampuan seseorang atau kelompok untuk memengaruhi tingkah laku orang atau kelompok lain sesuai dengan keinginan dari pelaku (Budiardjo, 2003). Kekuasaan merupakan kemampuan memengaruhi pihak lain untuk berpikir dan berperilaku sesuai dengan kehendak yang memengaruhi (Surbakti, 1992).

Hegemoni adalah sebuah rantai kemenangan yang didapat melalui mekanisme konsensus dalam melakukan penindasan terhadap kelas sosial lainnya. Hegemoni dalam sebuah kekuasaan berarti suatu bentuk dominasi atau penekanan yang dilakukan seseorang atau kelompok sosial sebagai pihak yang berkuasa kepada seseorang atau kelompok sosial yang lain untuk melakukan sesuatu yang dikehendakinya. 
Kepemimpinan atau kekuasaan menurut Gramsci dapat dibedakan atas dua jenis yaitu kepemimpinan (direction) dan dominasi (dominance) yang menyiratkan tiga hal. Pertama, dominasi dijadikan atas seluruh musuh dan dilakukan kepada segenap sekutunya. Kedua, hegemoni adalah suatu prakondisi untuk menaklukkan aparatur negara, atau dalam pengertian sempit kekuasaan pemerintahan. Ketiga, sekali kekuasan negara dapat dikuasai, dua aspek supremasi kelas ini, baik pengarahan maupun dominasi, akan terus berlanjut. Dalam kerangka teori Gramsci terdapat beberapa konsep kunci yaitu kebudayaan, ideologi, kaum intelektual, dan negara.

Pulang adalah novel yang diterbitkan oleh Republika tahun 2015 dengan tebal 400 halaman yang menggambarkan fakta-fakta sosiokultural yang terjadi pada masa novel itu diterbitkan. Berkaitan dengan shadow economy atau ekonomi bayangan yang dilakukan oleh kelompok-kelompok sosial tertentu, yang dalam novel ini dilakukan oleh tokoh utama Bujang dan kelompoknya, yang berpengaruh secara signifikan pada perekonomian global di suatu negara. Selain itu, juga usahanya mendominasi tokoh-tokoh politik dalam menentukan kebijakankebijakannya. Hal ini juga dikaitkan dengan hal-hal politik yang terjadi pada 1998 yaitu mulai dari melemahnya nilai rupiah, inflasi yang melambung, krisis moneter, hingga kudeta yang menumbangkan rezim orde baru.

Novel tersebut mengandung beberapa hal yang saling berkaitan antara kelas sosial yang satu dengan kelas sosial yang lain. Adanya bentuk kekuasaan terselubung yang kekuatannya dapat mengancam kekuasaan para penguasa negara. Bentuk kekuasaan yang mengancam kelas-kelas subordinat adalah keluargakeluarga pemegang kekuasaan dunia hitam yang lain dan juga menanamkan ideologi pada keluarga Samad sehingga secara halus tertindas oleh kekuasaan keluarga Tong. Hal ini berarti novel tersebut tidak dapat dipisahkan dari adanya konsep hegemoni dan permasalahan dominasi kelas sosial serta penanaman ideologi yang dianut tokoh.

\section{METODE}

Metode penelitian ini berupa metode penelitian kualitatif. Penelitian mengidentifikasi teks-teks novel dan mendeskripsikannya. Dalam penelitian ini, peneliti mendeskripsikan fakta-fakta yang ada dalam novel Pulang karya Tere Liye berdasarkan rumusan masalah kemudian disusul dengan menguraikan sampai pada tahap memberikan pemahaman dan penjelasan berdasarkan tujuan dari penelitian ini. Pendekatan yang digunakan dalam penelitian ini adalah pendekatan teori hegemoni Gramsci dengan kajian sosiologi sastra yang menganalisis karya sastra berdasarkan pendekatan internal dan eksternal.

Teknik pengumpulan data yang dilakukan dalam penelitian ini, yaitu teknik baca dan catat. Teknik baca yaitu membaca teks dari berbagai referensi tentang teori yang menjadi acuan penelitian dan yang terdapat dalam novel Pulang karya Tere Liye, sedangkan teknik catat dilakukan dengan cara mencatat teks berupa kata, frasa, atau kalimat yang sesuai dengan permasalahan yang ada dalam novel Pulang karya Tere Liye. Teknik analisis data berupa tahap identifikasi, tahap klasifikasi,

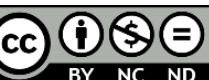

Creative Commons Attribution-NonCommercial-NoDerivatives 4.0 International License 
tahap analisis, dan tahap deskripsi. Tahap pembahasan meliputi pembuatan sekuen atau episode, menganalisis ruang dan waktu terjadinya suatu peristiwa, pengelompokkan kelas-kelas sosial dan analisis tokoh, dan pembuatan skema aktan.

Aktan adalah sesuatu yang abstrak seperti cinta, kebebasan, atau sekelompok tokoh. Aktan dalam teori Greimas menempati enam fungsi yaitu 1) subjek adalah seseorang yang ditugasi oleh pengirim untuk mendapatkan objek yang diinginkan; 2) objek adalah seseorang atau sesuatu yang diinginkan, dicari, atau diburu oleh pahlawan atas ide; 3 ) pengirim atau sender adalah seseorang atau sesuatu yang menjadi sumber ide dan berfungsi sebagai penggerak cerita; 4) penerima atau receiver adalah seseorang atau sesuatu yang menerima objek hasil buruan subjek; 5) penolong atau helper seseorang atau sesuatu yang membantu atau mempermudah usaha pahlawan dalam mencapai objek; dan 6) penentang atau opposant adalah seseorang atau sesuatu yang menghalangi usaha pahlawan untuk mencapai objek.

\section{HASIL DAN PEMBAHASAN}

\section{Hegemoni Kekuasaan yang Tercermin dalam Novel Pulang Tere Liye Sekuen atau Episode Pada Novel Pulang Karya Tere Liye}

Sekuen merupakan urutan satuan cerita yang dirangkai dalam satuan makna. Dalam novel Pulang Karya Tere Liye terdapat 80 sekuen yang berada berada pada saat penceritaan dan 46 sekuen pada saat sorot balik. Dari sekuen-sekuen yang telah dijabarkan secara detail, dapat dilihat peristiwa-peristiwa yang terjadi membentuk satu kesatuan yang dapat ditarik benang merahnya, yaitu tentang perjalanan kisah Bujang dalam upaya membantu Keluarga Tong menjalankan aksinya meraih kekuasaan dunia hitam, hegemoni kelas penguasa kepada kelas bawah, shadow economy, pertarungan, kesetiaan, penghianatan, perluasan kekuasaan, serta penemuan jalan pulang pada hakikat yang sebenarnya.

Tema utama yang digambarkan dalam novel tersebut adalah tentang hegemoni kekuasaan yang dilakukan oleh keluarga Tong yang didukung oleh jaringan-jaringan yang menggurita, baik di dalam dan di luar negeri. Banyaknya kaki tangan serta orang-orang kepercayaan tersebut menjadikannya besar dan menguasai hampir seluruh bidang perekonomian. Hal tersebut terdapat pada sekuen 3 dan 4, dalam penceritaan, ketika Bujang mendatangi ruang kerja Calon Presiden berkemeja putih di ruangan bernuansa tradisional yang terlihat nyaman dengan lantai marmer yang mengkilap untuk menyampaikan pesannya tentang shadow economy.

Berdasarkan penjelasan tersebut diketahui bahwa hegemoni kekuasaan keluarga Tong tercermin dalam setiap alur penceritaan, baik dalam sekuen penceritaan ataupun saat sorot balik yang digambarkan dalam alur campuran.

\section{Hegemoni Kekuasaan dalam Penokohan Novel Pulang Karya Tere Liye Tokoh sebagai Anggota Masyarakat / Kelas Sosial}

Pada penelitian ini, tokoh ditempatkan sebagai wakil dari kelas-kelas sosial di masyarakat. Dalam novel tersebut tokoh sebagai wakil kelas sosial terbagi 
menjadi dua kelompok, yaitu kelompok sosial penguasa dan kelas sosial bawah, selanjutnya disebut kelas sosial terhegemoni.

\section{a. Kelas Sosial Penguasa (Etnis Tionghoa)}

Kelas sosial penguasa adalah kelas sosial yang secara sadar mengotrol, mengendalikan, serta mendominasi kelas sosial bawah untuk melakukan sesuatu sesuai yang dikehendakinya membantu mewujudkan misinya. Adapun kelas sosial penguasa pada novel ini adalah keluarga Tong, termasuk Bujang dan Kelompok Master Dragon. Dari nama-nama tokoh tersebut diketahui bahwa sebagian besar mereka merupakan kelompok orang Cina/etnisTionghoa yang dibantu oleh Bujang yang merupakan masyarakat pribumi. Mereka bergerak dalam bisnis kekuasaan shadow economy yang menguasai sebagian besar perekonomian dunia.

\section{1) Keluarga Tong}

Gambaran fisik keluarga Tong digambarkan pada sosok Tauke Besar yang merupakan kepala keluarga dalam keluarga tersebut. Hanya disebutkan bahwa ia bermata sipit, bertubuh pendek, dan gempal. Dengan penjelasan tersebut, pembaca dapat membayangkan bahwa Tauke Besar mempunyai ciri seperti Tauke-Tauke pada umumnya.

Tauke adalah seorang yang ambisius, keinginan seperti sosok ayah menjadikannya selalu berpikir, berencana, dan berstrategi, hingga akhirnya mampu menguasai perekonomian dunia. Hal itu didukung dengan kutipan bertikut:

Tauke tidak pernah berhenti. Setiap hari melakukan pertemuan, merancang sesuatu, atau mengeksekusi sesuatu. Setiap bulan perusahaannya bertambah. Setiap tahun satu demi satu kota ditaklukkan. Tauke selalu dipengarui mimpi-mimpi baru. Dia tidak pernah puas, hingga sakit sumsum tulang belakang membuatnya terbaring di atas kasur (Liye, 2015: 206).

Tauke merupakan perancang strategi yang handal, memiliki visi dan misi yang jelas untuk masa depan keluarganya yang gemilang. Selain itu juga seorang yang cerdas, dengan kecerdasan serta keinginan mewujudkan ambisinya, Tauke memperluas gurita kekuasaan dengan membuat rencanarencana besar, merancang strategi, tak-tik, menggerakkan pion-pion,serta mencari potongan-potongan puzzle yang menyempurnakan rencananya, termasuk menemukan Bujang seorang pribumi yang berasal dari Langkat, Bukit Barisan, Sumatra, sebagai potongan Puzzle terakhirnya.

Dengan strategi Taukelah, akhirnya Bujang menjadi bagian dari keluarga Tong sebagai puzzle, spesialisasi penyelesai konflik tingkat tinggi yang menjalankan hegemoni kekuasaan. Penggambaran tokoh Tauke yang mewakili keluarga Tong, merupakan pengakuan masyarakat tentang kelompok-kelompok Cina yang berkuasa dalam praktik dunia hitam atau shadow economy yang menguasai $20 \%$ GDP di Indonesia.

\section{2) Kelompok Master Dragon}

Hampir tidak ada penggambaran fisik Master Dragon. Hanya digambarkan sebagai seorang yang berambut memutih, terlihat segar, 
matanya berkilau tajam, garis wajahnya terlihat tegas, dan rahangnya terlihat kokoh. Gambaran fisik yang dapat dimiliki oleh siapa saja, tidak menampilkan ciri khas kelompok tertentu.

Master Dragon adalah seorang yang beretnis Tionghoa yang tinggal di kawasan Kowloon, Hong Kong. Ia adalah seorang yang kuat karena kekuasaannya sebagai kepala seluruh keluarga dunia hitam yang beroperasi di seluruh dunia. Dengan kekuasaannya, menjadikannya orang yang sangat disegani oleh para pelaku bisnis dunia hitam, termasuk dalam pemerintahan. Hal itu tercermin pada kutipan berikut:

Dialah kepala seluruh keluarga. Semua orang memanggilnya Master Dragon. (...). Dengan kekuasaan gelapnya, dia bisa mengubah hasil pemilu negara-negara maju dan menunjuk Presiden yang dia sukai (Liye, 2015: 74).

Bahkan kekuasaan gelapnya dapat mengubah hasil pemilu di negara-negara maju dan menunjuk presiden yang ia sukai.

Penggambaran tokoh Master Dragon yang mewakili kelompoknya, merupakan suatu pengakuan masyarakat tentang kelompok-kelompok pelaku bisnis dunia di seluruh dunia yang berkuasa dalam praktik dunia hitam.

Kedua kelas sosial tersebut merupakan kelompok ber-etnisTionghoa diceritakan menjadi penguasa dunia hitam. Dalam menjalankan bisnis dunia hitamnya tersebut, mereka menghegemoni atau mendominasi kelas sosial lain sehingga baik dengan sukarela ataupun terpaksa bersedia membantu memuluskan usahanya mencapai kekuasaan dunia hitam. Hegemoni kekuasaan tergambar dalam caranya berpikir, berencana, dan berstrategi hingga akhirnya mampu menguasai perekonomian dunia.

\section{b. Kelas Sosial Terhegemoni (Pribumi dan Nonpribumi)}

Kelas sosial terhegemoni adalah kelas sosial yang perilakunya didominasi dan dikontrol oleh kelas sosial penguasa. Sikap, pemikiran, dan tingkah lakunya tidak dapat dilakukan atas kehendak pribadi tetapi dikendalikan oleh kelas sosial penguasa.

Adapun kelas sosial terhegemoni yang terdapat pada novel ini adalah keluarga Samad, pemerintah, anak buah keluarga Tong.

\section{1) Keluarga Samad}

Hampir tidak ada penggambaran fisik pada tokoh Samad dan keluarganya, hanya digambarkan bahwa Samad sebagai kepala keluarga (bapak Bujang) berperawakan tinggi dengan kaki lumpuh satu akibat usahanya menyelamatkan Tauke Besar yang dahulu, ayah Tauke Besar yang sekarang dalam perebutan kekuasaan oleh kelompok lain. Gambaran fisik yang dapat dimiliki oleh siapa saja, akan tetapi terdapat penyebutan bahwa ia seorang yang berasal dari Langkat Hutan Bukit Barisan Sumatera. Maka diketahui bahwa ia seorang pribumi.

Kesetiaan Samad terlihat ketika ia dengan rela menyerahkan anak semata wayangnya (Bujang) pergi bersama Tauke Muda untuk menggantikan dirinya yang telah mundur sebagai tukang pukul.

\section{2) Pemerintah}


Tidak ada penggambaran khusus secara fisik pada kelompok pemerintah, hanya disebutkan Calon Presiden berkemeja Putih. Akan tetapi hal itu telah mewakili identitas calon presiden tertentu yang mencalonkan diri pada pilihan presiden tahun 2014. Pada novel Pulang karya Tere Liye ini, pemerintah menjadi bagian kelas sosial yang terhegemoni oleh kekuasaan dunia hitam Keluarga Tong. Meskipun secara sah menjadi pemegang kekuasaan tertinggi, ternyata masih terbatasi oleh kekuasaan masif para pelaku shadow economy, dunia hitam.

Pada peristiwa ini, pemerintah digambarkan menjadi pihak yang tidak berdaya melawan gurita kekuasaan keluarga Tong beserta jaringannya. Dalam menentukan kebijakan nanti, apabila terpilih, harus tetap membiarkan bisnis shadow economy terus berjalan. Pengambilan kebijakan tidak sepenuhnya dapat dilakukan secara objektif untuk kepentingan rakyat. Hal itu dapat dilihat pada kutipan berikut:

"Kami ada di mana-mana Bapak Calon Presiden, jangan pernah main-main dengan kami. Jangan ganggu kami, maka kami tidak akan mengganggu Anda. Silakan Anda menjual program ekonomi apapun, kartu sakti, pemberantasan korupsi, dan entahlah omong kosong kampanye itu. Anda punya urusan sendiri, kami juga punya."(Liye, 1995: 34-35).

Kutipan tersebut menggambarkan ketidakberdayaan pemerintah akan kekuasaan masif yang menggurita dalam semua sendi perekonomian yang menjalankan usahanya dengan kekerasan, kecurangan, serta menghalalkan segala cara.

\section{3) Anak Buah Keluarga Tong, Masyarakat Pribumi dan Nonpribumi}

Tidak terdapat penggambaran secara fisik pada anak buah keluarga Tong, baik yang berperan sebagai tukang pukul, pelayan, kaki tangan, maupun koleganya. Begitu juga dengan Mansur dan Kopong yang tidak dideskripsikan secara jelas. Hampir semua merupakan masyarakat pribumi, hanya ada beberapa yang merupakan masyarakat nonpribumi. Penggambaran fisik hanyalah penyebutan biasa yang tidak mencirikan sebagai kelompok sosial tertentu.

Ketiga kelas tokoh yang tergabung ke dalam kelas sosial terhegemoni ini pada umumnya adalah masyarakat pribumi, yang menjadi kelas sosial yang dikuasai oleh penghegemoni. Peristiwa hegemoni kekuasaan terhadapnya digambarkan melalui kepatuhan, kepasrahan, ketidakberdayaan, serta kesetiaannya kepada kelas sosial penghegemoni.

Kesetiaan Samad kepada keluarga Tong juga merupakan gambaran bahwa dirinya terhegemoni secara sukarela oleh kekuasaan keluarga tersebut. Begitu juga dengan ketidakberdayaan pemerintah untuk melawan dan menumpaskan praktik shadow economy dunia hitam, yang justru menggulingkannya dari kekuasaannya enam periode berturut-turut.

\section{Skema Aktan pada Novel Pulang}

Aktan merupakan pelaku tindakan, peran yang hadir dalam tindakan, yang dapat ditempati oleh segala macam entitas. 


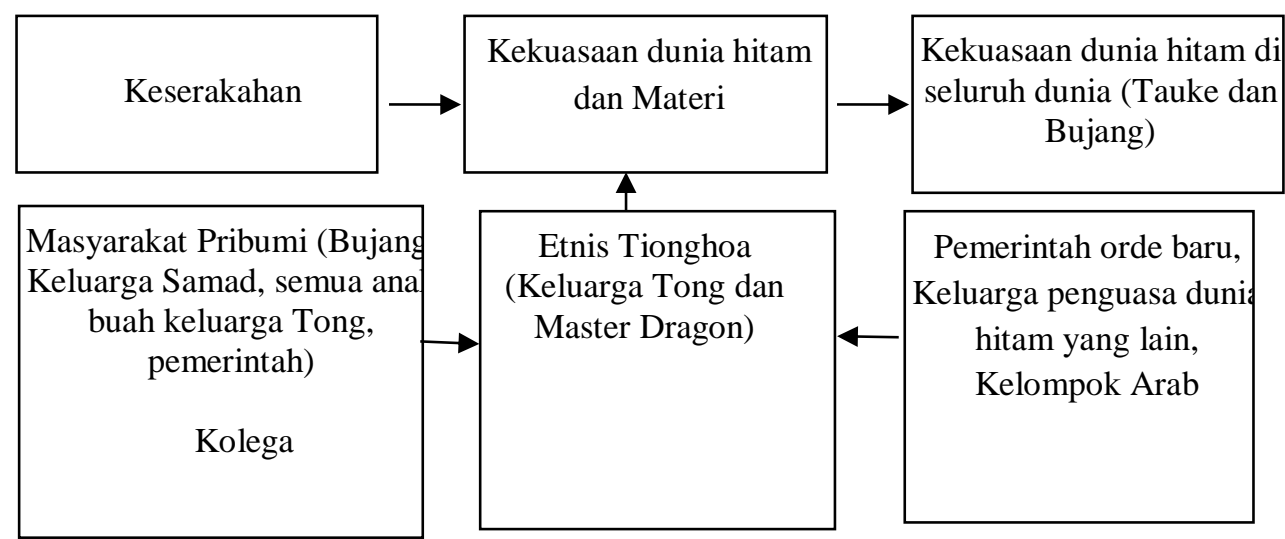

Gambar 1. Skema Aktan dalam novel Pulang

Pada skema aktan tersebut terlihat bahwa pengirim dalam novel Pulang karya Tere Liye adalah keserakahan kelompok sosial penguasa, keluarga Tong dan Master Dragon (beretnisTionghoa). Hal tersebut menjadi motor penggerak bagi subjek untuk mendapatkan objek yaitu kekuasaan dunia hitam serta materi yang berlimpah yang mendukung tujuan tersebut.

Subjek dalam novel tersebut adalah para pelaku dunia hitam sebagai kelas berkuasa, yaitu keluarga Tong dan Master Dragon. Kelompok sosial tersebut terpanggil oleh pengirim untuk mendapatkan objek yang diinginkan. Dengan nafsu keserakahannya sebagai penguasa dunia hitam, mereka ingin mendapatkan kekuasaan serta materi sehingga dapat menghalalkan segala dengan memanggil para pahlawannya, masyarakat pribumi dan nonpribumi untuk menjalankan rencana dan strateginya.

Penentang atau kelompok sosial yang menentang subjek dalam mencapai objek yang akan dicapai pada novel ini adalah pemerintah rezim orde baru, keluarga penguasa dunia hitam lain, kelompok Arab, keluarga Lin, serta Basyir.

Penolong atau pembantu keluarga Tong sebagai kelas berkuasa terdiri dari anggota masyarakat pribumi maupun nonpribumi. Anggota masyarakat pribumi yang menjadi pembantu keluarga Tong dalam mendapatkan objek adalah Bujang, Samad, Kopong, Mansur, dan seluruh anak buah yang terdiri dari tukang pukul, pelayan, dan kaki tangan. Penerima objek yang didapat dalam pencarian oleh subjek dalam novel Pulang karya Tere Liye tersebut yaitu Tauke Besar dan Bujang.

\section{Hegemoni Kekuasaan dalam Ruang dan Waktu pada Novel}

Penggambaran hegemoni kekuasaan dalamlatartempat dan waktu yang terdapat pada novel ini adalah sebagai berikut:

a. Markas besar Keluarga Tong di Kota Provinsi

Ada seratus orang yang tinggal di rumah Tauke. Sebagian besar adalah tukang pukul, mereka tinggal di sayap kanan dan belakang bangunan utama. (...) Sisanya adalah pelayan, bagian keuangan, logistik, medis, dan apapun yang dibutuhkan rumah itu agar berjalan lancar, tinggal di mess sayap kiri (Liye, 2015: 43). 
Tidak ada pendeskripsian latar tempat yang spesifik tentang markas besar keluarga Tong, hanya digambarkan tentang tempat tinggalnya para tukang pukul dan pelayan serta apapun yang dibutuhkan keluarga tersebut. Hal itu menunjukkan hegemoni kekuasaan yang kuat keluarga tersebut didukung oleh kaki tangan serta jaringan-jaringannya yang menggurita untuk menancapkan kekuasaan.

b. Ruangan bernuansa tradisional, tahun 2014 dengan suasana menegangkan Ruangan dengan nuansa tradisional itu terlihat nyaman.Lantai marmernya mengkilap.Ada meja panjang yang terbuat dari kayu jati pilihan dan beberapa kursi empuk. (...). Dua orang masuk, salah satunya adalah sosok yang paling sering diliput dan diberitakan oleh media nasional belakangan.Ia mengenakan kemeja putih lengan panjang. Di belakangnya ikut melangkah seseorang yang dikenali sebagai penasihat kampanye bidang ekonomi (Liye, 2015: 27).

Pendeskripsian ruangan dengan nuansa tradisional yang digambarkan nyaman dengan marmer mengkilap sebagai ruangan kerja calon presiden yang diceritakan sering memakai kemeja putih sebagai identitas dalam kampanyenya pada pilihan presiden 2014. Ruangan tersebut menjadi latar tempat ketika Bujang menyampaikan pesannya tentang shadow economy dari keluarga Tong, yang menggambarkan adanya hegemoni kekuasaan oleh keluarga tersebut. Kekuasaan keluarga Tong terlihat dari disambutnya Bujang oleh calon presiden, bahkan sampai menunda jadwal kampanye yang telah direncanakan sebelumnya.

Selain itu, di tempat itu pulalah Bujang mengingatkan kepada calon presiden tentang penggulingan kekuasaan rezim orde baru yang terjadi pada tahun 1998 karena ketidaksepakatannya dengan penguasa dunia hitam dalam menjalankan urusannya masing-masing di dalam negeri.

c. Markas Besar Keluarga Tong di ibu kota

"Kau akan pangling melihat markas besar kita, Bujang. Ada banyak bangunan baru di sana. Kamar kau berubah lebih luas, lebih bagus, dan langsung terhubung dengan bangunan utama. Aku juga membuat banyak sistem keamanan baru, menambahkan lorong-lorong bawah tanah, jalur darurat, dan sistem otomatis.Mungkin kau bisa memberikan masukan setelah melihatnya."

Penggambaran latar, markas keluarga Tong di Ibu Kota sebagai markas besar yang luas dan bagus, disertai penyiapan sistem-sistem pengamanan baru yang tentunya menggunakan teknologi mutakhir, penyiapan lorong-lorong bawah tanah sebagai jalur evakuasi darurat saat terjadinya penyerbuan yang tidak diinginkan, dilengkapi dengan sistem otomatis, merupakan penggambaran hegemoni kekuasaan yang luar biasa telah direncanakan keluarga Tong. Suatu benteng pertahanan yang sulit untuk ditembus oleh musuh, hal ini menyiratkan bahwa kekuatan besar keluarga tersebut yang sulit dikalahkan.

d. Halaman rumah Tuanku Imam

Pada Novel Pulang karya Tere Liye, sebagian besar keterangan ruang dan waktu dideskripsikan dengan jelas, serta beberapa di antaranya 
menunjukkan adanya hegemoni kekuasaan yang dilakukan oleh kelas sosial penguasa. Hegemoni kekuasaan terlihat jelas pada penggambaran ruang dan waktu di markas besar Keluarga Tong, baik di kota provinsi maupun di ibu kota, di ruangan bernuansa tradisional.

\section{Deskripsi Ideologi Kelas-Kelas Sosial disajikan dalam Novel Pulang}

Ideologi merupakan sistem ide yang terjelma dalam cara hidup kolektif masyarakat, bukan meliputi pemikiran perseorangan pada tataran individual. Seperti yang telah dikemukakan pada bagian pembahasan sebelumnya bahwa dalam penelitian yang bersifat sosial-historis, tokoh-tokoh yang terdapat pada novel tidak dicerminkan sebagai individu, akan tetapi mewakili kelompok sosial tertentu sebagai perwujudan kritik sosial.

Terdapat perbedaan yang menonjol antara ideologi yang dianut oleh kelompok penguasa dan kelompok yang dikuasai.

\section{Ideologi Kelas Sosial Penguasa / Pelaku Dunia Hitam}

Ideologi yang dianut oleh kelas sosial penguasa di antaranya adalah menempatkan kekuasaan di atas segalanya, menghalalkan segala cara, serta berorientasi pada materi.

\section{a. Menempatkan kekuasaan di atas segalanya}

Kelas sosial penguasa selalu menempatkan kekuasaan di atas segalanya. Hal itu terlihat dari cara-cara, tak-tik, strategi, maupun rencanarencana besarnya untuk memperoleh kekuasaan yang dirancang dengan hati-hati, teliti, dan penuh pertimbangan.

"Masih ada beberapa keluarga lain yang berkuasa di Ibu Kota. Mereka menguasai teritorial tertentu dan cukup tangguh karena bisa bertahan dari gempuran Keluarga Tong. Tapi kita akan menaklukannya cepat atau lambat." (Liye,2015:229)

Mereka berupaya kuat untuk menjadi satu-satunya keluarga yang menguasai seluruh sendi perekonomian di ibu kota yang diwujudkan melalui kerjasama, saling bahu-membahu untuk mewujudkan tujuan. Keluarga Tong menghabisi keluarga lain yang telah menyerang markas ataupun daerah teritorial kekuasaannya, menumpas sampai ke akar-akarnya, membumi hanguskan seluruh anggota keluarganya, hingga anak-anak dan para perempuan. Penjelasan-penjelasan tersebut cukup membuktikan bahwa ideologi keluarga Tong, yang mewakili pelaku dunia hitam adalah menempatkan kekuasaan di atas segalanya.

b. Kekuasaan diperoleh dengan menghalalkan segala cara

Mengingat bahwa salah satu ideologi yang dimiliki keluarga Tong adalah menempatkan kekuasaan di atas segalanya, mereka akan menghalalkan segala cara untuk mengupayakannya.

"Kami akhirnya berhasil menguasai Pasar Induk...Kopong sedang menyelesaikan sisanya, menyumpal mulut petugas dan wartawan agar kejadian tidak tersebar kemana-mana.Kopong ahli sekali dalam hal itu, dan orang-orang hanya akan melihatnya seperti kebakaran dan rusuh biasa. (Liye, 2015: 53). 
Demi mendapatkan kekuasaan, mereka rela menghalalkan segala cara. Hal-hal yang seharusnya tidak dilakukanpun ternyata ditempuh juga, termasuk menyerbu keluarga lain untuk menguasai pelabuhan hingga terbakar. Berikut menyumpal atau menyuap petugas serta wartawan agar tidak memberitakan hal-hal yang menyangkut peristiwa tersebut atau dengan kata lain membelokkan fakta.

c. Kekuasaan dapat diupayakan dengan uang

Ideologi lain yang dianut keluarga Tong adalah kekuasaan dapat diupayakan dengan uang. Uang menjadi modal dalam mewujudkan dan menyebarkan gurita-gurita kekuasaan. Dengan sarana tersebut, bisnis yang menguasai segala sendi perekonomian dapat dikembangkan.

"Kita memiliki puluhan properti penting "Bisnis perbankan kita juga berjalan baik. Asetnya tumbuh berkali-kali lipat, sehingga kita punya banyak uang untuk berkembang. Tauke juga menyuruh Mansur mengurus bisnis keuangan lainnya, mulai dari asuransi, investasi, pasar modal"'( Liye, 2015:229)

Kepemilikan properti-properti penting yang menyangkut kepentingan orang banyak, yang diperoleh dengan uang, dapat mempengaruhi kebijakan-kebijakan pemerintah sekalipun. Bahkan ekstremnya dapat mempermainkan dan membombardir valas, seperti yang telah dilakukan pada upaya penggulingan rezim orde baru (telah disebutkan sebelumnya). Hal tersebut menunjukkan bahwa ideologi mereka, uang dapat mengupayakan kekuasaan.

\section{d. Kekuasaan dan kejayaan dibangun dengan kerja sama}

Kekuasaan dan kejayaan dapat dibangun dengan adanya kerja sama merupakan salah ideologi yang dianut keluarga Tong. Tanpa kerja sama dari seluruh pendukung, kaki tangan, serta jaringannya, Keluarga Tong bukanlah siapa-siapa. Mereka tidak akan mampu menguasai dan menyebarkan gurita kekuasaannya sendirian. Semangat persatuan, kerja sama, bahu-membahu antaranggota keluarga Tong beserta dengan kolega-kolega dan jaringannya tersebut, mereka kuat dan terus bertahan bahkan menaklukkan dunia.

\section{Ideologi Kelas Sosial yang dikuasai}

Ideologi yang dianut oleh kelas sosial yang dikuasai jauh berbeda dengan kelas sosial penguasa. Adapun ideologi yang dianutnya sebagai berikut:

a. Setia kepada penguasa

Salah satu ideologi kelas sosial terhegemoni adalah setia kepada penguasa. Kesetiaan tersebut dapat ditunjukkan dengan berbagai cara. Salah satu wujud kesetian keluarga Samad ditunjukkan dengan tetap menepati janji masa lalunya.

Kesetian Samad sebagai salah satu kelas sosial terhegemoni, kepada keluarga Tong adalah dengan cara tetap menepati janji masa lalunya yaitu dengan rela menyerahkan anak semata wayangnya (Bujang), pergi bersama Tauke Muda, sebagai tebusan atas pengunduran dirinya sebagai tukang 
pukul dari keluarga tersebut.

Selain Samad, kesetiaan juga ditunjukkan oleh Frans dan White sebagai kaki tangan sekaligus kolega Keluarga Tong. Kesetiaan mereka terpanggil saat keluarga Tong mengalami masalah besar, yaitu penghianatan Basyir yang mengakibatkan meninggalnya Tauke. Kesetiannya dibuktikan dengan turut sertanya dalam upaya perebutan kembali markas besar dari Basyir. Penjelasan tersebut menunjukkan bahwa ideologi yang dianut kelas sosial kelas terhegemoni adalah setia kepada penguasa

b. Kepatuhan kepada penguasa

Ideologi lain yang ditunjukkan oleh kelas sosial terhegemoni adalah kepatuhan kepada penguasa.

"Ini hanya usul sederhana, Tauke. Aku harap Tauke memikirkannya.Apa pun keputusan Tauke adalah perintah bagiku." Kopong mengangguk, undur diri (Liye,2015:94).

\section{Kaitan Hegemoni Kekuasaan dengan Ideologi dalam Novel Pulang}

Terjadinya hegemoni kekuasaan berkaitan erat dengan ideologi yang dianut oleh tokoh sebagai wakil dari kelas sosial tertentu. Kelas penguasa menghegemoni kelas bawah karena ideologi yang dimilikinya yaitu menempatkan kekuasaan di atas segalanya, menghalalkan segala cara, kekuasaan dapat diupayakan dengan uang, serta kekuasaan dan kejayaan dibangun dengan kerja sama. Ideologi tersebut sangat memungkinkan kelas sosial tersebut untuk melakukan hegemoni kelas sosial yang lain sebagai kaki tangan maupun jaringannya untuk mencapai kekuasaan. Selain itu, hegemoni juga dilakukan kepada kelas sosial lain yang berkuasa, dengan cara kekerasan dan penyerbuan sehingga kekuasaan seutuhnya dapat dicapai.

Ideologi yang dimiliki kelas sosial bawah membuka peluang untuk menjadi kelompok yang terhegemoni. Dengan kepatuhan serta kesetiaannya kepada penguasa menjadikannya dapat dikontrol dan dikendalikan oleh kekuasaan tersebut. Apa yang dikatakannya merupakan perintah yang harus dikerjakan. Hal itu membuka peluang untuk menjadi pihak yang terhegemoni.

\section{Penafsiran dan Uraian}

Berdasarkan pembahasan serta deskripsi tersebut, dapat diketahui bahwa dalam novel Pulang Karya Tere Liye terdapat 80 sekuen yang berada berada pada saat penceritaan dan 46 sekuen pada saat sorot balik. Dari sekuen-sekuen yang telah dijabarkan secara detail, dapat dilihat peristiwa-peristiwa yang terjadi membentuk satu kesatuan yang dapat ditarik benang merahnya, yaitu tentang perjalanan kisah Bujang dalam upaya membantu keluarga Tong menjalankan aksinya meraih kekuasaan dunia hitam, hegemoni kelas penguasa kepada kelas bawah, shadow economy, pertarungan, kesetiaan, penghianatan, perluasan kekuasaan, serta penemuan jalan pulang pada hakikat yang sebenarnya.

Tema utama yang digambarkan dalam novel tersebut adalah tentang hegemoni kekuasaan yang dilakukan oleh keluarga Tong yang didukung oleh jaringan-jaringan yang menggurita baik di dalam dan di luar negeri. Banyaknya kaki tangan serta orang-orang kepercayaan tersebut menjadikannya besar dan menguasai hampir seluruh bidang perekonomian. Penancapan hegemoni kekuasaan 
tersebut tercermin dalam setiap alur, baik dalam sekuen penceritaan ataupun saat sorot balik yang digambarkan dalam alur campuran.

Penelitian dengan pendekatan sosiologi sastra ini menempatkan tokoh sebagai kelas-kelas sosial yang dalam novel tersebut terbagi menjadi dua kelas sosial; kelas sosial penguasa dan yang dikuasai. Kelas sosial penguasa merupakan kelompok beretnis Tionghoa diceritakan sebagai penguasa dunia hitam atau shadow economy yang menguasai hampir 20\% GDP dunia. Dalam menjalankan bisnis dunia hitamnya, mereka menghegemoni atau mendominasi kelas sosial lain sehingga baik dengan sukarela ataupun terpaksa bersedia membantu memuluskan usahanya mencapai kekuasaan. Hegemoni kekuasaan tergambar pada caranya berpikir, berencana, dan berstrategi hingga akhirnya mampu menguasai perekonomian dunia. Termasuk di dalamnya kegigihan menemukan dan membentuk potongan puzzle terakhirnya, yaitu Bujang, sebagai salah satu kunci, yang memiliki spesialisasi penyelesai konflik tingkat tinggi.

Kelas sosial yang dikuasai pada umumnya adalah masyarakat pribumi, yang menjadi kelas sosial yang dikuasai oleh penguasa. Peristiwa hegemoni kekuasaan terhadapnya digambarkan melalui kepatuhan, kepasrahan, ketidakberdayaan, serta kesetiaannya kepada kelas sosial tersebut. Seperti yang dicerminkan anak buah keluarga Tong yang terdiri dari tukang pukul, pelayan, kaki tangan, serta kolegakoleganya.

Kesetiaan Samad kepada keluarga Tong juga merupakan gambaran bahwa dirinya terhegemoni secara tidak sadar oleh kekuasaan keluarga tersebut. Begitu juga dengan ketidakberdayaan pemerintah untuk melawan dan menumpaskan praktik shadow economy dunia hitam, yang justru menggulingkannya dari kekuasaannya selama enam periode berturut-turut.

Hegemoni kekuasaan terlihat jelas pada penggambaran ruang dan waktu di markas besar Keluarga Tong, baik di kota provinsi maupun di ibu kota, di ruangan bernuansa tradisional, dan di halaman rumah Tuanku Imam,

Selain itu, digambarkan juga ideologi kelas sosial penguasa yang menempatkan 1) kekuasaan di atas segalanya; 2) kekuasaan diperoleh dengan menghalalkan segala cara; 3) kekuasaan dapat diupayakan dengan uang; dan 4) kekuasaan serta kejayaan dapat dibangun dengan kerja sama. Begitu juga dengan ideologi kelas sosial yang dikuasai; 1) kepatuhan; dan 2) kesetiaan terhadap penguasa, yang tergambar dalam rangkaian alur, baik dalam penceritaan maupun dalam sorot balik.

\section{SIMPULAN}

Mengacu pada rumusan masalah serta hasil analisis dan pembahasan pada bab sebelumnya tentang hegemoni kekuasaan dan ideologi dalam novel Pulang karya Tere Liye, dengan pendekatan sosiologi sastra dan semiotika, dapat disimpulkan bahwa terjadinya hegemoni kekuasaan dari kelas penguasa berkaitan erat dengan ideologi yang dianut tokoh sebagai wakil dari kelompok sosial tertentu; ideologi penguasa yang menempatkan kekuasaan di atas segalanya, menghalalkan segala cara, kekuasaan dapat diupayakan dengan uang, serta kekuasaan dan 
kejayaan dibangun dengan kerja sama, mengakibatkannya melakukan hegemoni kepada kelas sosial rendah yang berideologi setia dan patuh kepada penguasa.

Hegemoni kelas berkuasa pelaku bisnis dunia hitam atau shadow economy terjadi kepada kelas sosial lain yang dikuasai, baik secara sukarela maupun terpaksa, yang disajikan pada penokohan, latar ruang dan waktu, serta dalam setiap alur cerita, baik dalam penceritaan maupun sorot balik, digambarkan pada kisah perjalanan Bujang dalam mendukung keluarga Tong dalam praktik tersebut.

Ideologi kelas berkuasa maupun kelas yang dikuasai, tergambar secara jelas pada setiap peristiwa yang terjalin dalam kesatuan alur yang menantang, keutuhan serta kesatuan isi dan makna yang dijalin secara runtut, yang mengakibatkan hegemoni kekuasaan dapat terjadi, sehingga pengarang mampu menyampaikan kritik sosialnya secara jelas, dan lugas.

\section{DAFTAR PUSTAKA}

Budiardjo, M. (2003). Dasar-Dasar Ilmu Politik. Gramedia Pustaka Utama. Liye, T. (2015). Pulang. Jakarta: Republika.

Purba, A. (2010). Sastra Indonesia Kontemporer. Yogyakarta: Graha Ilmu.

Rokhmansyah, A. (2010) Sastra Sebagai Cerminan Masyarakat. Phianzsotoy.blogspot.co.id/2010/06/sastra-sebagai-cerminmasyarakat.html.

Surbakti, R. (1992). Memahami ilmu politik. Grasindo.

Wellek, Rene dan Austin Warren. (2000). Teori Kesusastraan. Jakarta: PT. Gramedia Pustaka Utama. 